\title{
Pengembangan LKPD Berbasis Kontekstual dalam Pembelajaran Fisika SMA Pada Materi Elastisitas
}

Bahan

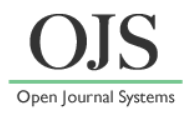

\author{
Rizqi Nur Firdausi", Imam Sucahyo \\ Program Studi Pendidikan Fisika, Jurusan Fisika, FMIPA, Universitas Negeri Surabaya \\ *Email: rizqi.17030184032@mhs.unesa.ac.id
}

DOI: https://doi.org/10.33369/pendipa.5.3.351-358

\begin{abstract}
Physics is a science that is usually found in everyday life. The presentation of learning physics, it will be easier if related to daily activities. Linking learning with everyday life is called contextual learning. Learning physics with a contextual-based approach is considered the most suitable to be used. There have been many studies regarding the development of student worksheet on the elasticity of this material. However, until now there has not been found student worksheet for material elasticity of materials with a contextual-based approach that is valid and practical to use. This contextual-based student worksheet development research refers to the 4-D research model (define, design, develop and disseminate) but without going through the dissemination stage. The validity of this contextual-based student worksheet was tested by two media expert validators which were then followed by an open trial. In the open trial, it was carried out online by giving a random response questionnaire to class XI high school students in the Gresik district. Data from the validity process and open testing were analyzed through descriptive quantitative. The results showed that the contextual-based student worksheet on the elasticity of this material obtained the validity results of the expert team with an average of $94 \%$ which was included in the very valid category. Furthermore, in the open trial stage, students gave a response by getting an average score of $98 \%$ which was classified as very good with practical meaning to use. Therefore, the contextualbased student worksheet on the material elasticity of this material is very feasible and practical to be used in the teaching and learning process in class XI high school with material elasticity material.
\end{abstract}

Keywords: Student worksheet validity, student worksheet practicality, contextual, material elasticity.

\begin{abstract}
ABSTRAK
Ilmu fisika merupakan salah satu ilmu yang biasanya dijumpai dalam kehidupan sehari-hari. Sehingga dalam pemaparan pembelajaran fisika akan lebih mudah jika dikaitkan dengan kegiatan sehari-hari. Pengaitan pebelajaran dengan kehidupan sehari-hari disebut dengan pembelajaran kontekstual. Pembelajaran fisika dengan pendekatan berbasis kontekstual dirasa paling sesuai untuk digunakan. Telah banyak penelitian mengenai pengembangan Lembar Kerja Peserta Didik (LKPD) pada materi elastisitas bahan ini. Namun, hingga saat ini belum ditemui LKPD untuk materi elastisitas bahan dengan pendekatan berbasis kontekstual yang valid dan praktis unutk digunakan. Penelitian pengembangan LKPD berbasis kontekstual ini merujuk pada model penelitian 4-D (define, design, develop and disseminate) namun tanpa melalui tahapan disseminate atau penyebaran. Validitas LKPD berbasis kontekstual ini diuji oleh dua validator ahli media yang kemudian dilanjutkan dengan uji coba terbuka. Pada uji coba terbuka dilakukan secara online dengan pemberian angket respons kepada peserta didik SMA kelas XI secara acak di kabupaten Gresik. Data dari proses validitas dan uji coba terbuka ini dianalisis secara deskriptif kuantitatif. Hasil penelitian menunjukkan bahwa LKPD berbasis kontekstual pada materi elastisitas bahan ini mendapatkan hasil validitas tim ahli dengan rata-rata $94 \%$ yang
\end{abstract}


termasuk dalam kategori sangat valid. Selanjutnya pada tahap uji coba terbuka diberikan respons oleh peserta didik dengan mendapatkan skor rata-rata $98 \%$ yang tergolong sangat baik dengan arti praktis untuk digunakan. Oleh karena itu, LKPD berbasis kontektual pada materi elastisitas bahan ini sangat layak dan praktis untuk digunakan dalam proses belajar mengajar pada kelas XI SMA dengan materi elastisitas bahan.

Kata Kunci: Validitas LKPD, kepraktisan LKPD, kontekstual, elastisitas bahan.

\section{PENDAHULUAN}

Terdapat berbagai permasalahan dalam mengajarkan ilmu fisika disekolah. Menurut Zulhaini, dkk (2016) berdasarkan hasil wawancara dengan guru MAN Banda Aceh kesulitan mengajar fisika adalah karena peserta didik sulit memahami konsep fisika karena fokusnya pada rumus yang banyak. Selain itu Menurut Yusmanila, dkk (2017) peserta didik beranggapan bahwa fisika merupakan ilmu yang abstrak, sulit dimahami, tidak nyata dan hanya berisi kumpulan dari berbagai rumus.

Sedangkan menurut Peraturan Menteri tahun 2004 Nomor 059 fisika merupakan ilmu yang (1) memperoleh informasi dengan metode empiris; (2) diperoleh secara logis dan sistematis; dan (3) kombinasi proses berpikir kritis yang menghasilkan informasi yang dapat dipercaya dan valid. Berdasarkan peraturan menteri di poin (1) ilmu fisika diperoleh berdasarkan fakta yang telah terjadi. Dapat diartikan setiap kegiatan yang dilakukan dalam kehidupan sehari-hari berhubungan erat dengan ilmu fisika. Hal ini dapat dijadikan acuan pada saat melakukan pembelajaran disekolah.

Sesuai dengan pendidikan sekolah saat ini yang menganut kurikulum 2013 dimana fokus pada kurikulum ini adalah proses pembelajaran yang didesain agar peserta didik berproses secara fisik maupun mental dengan berbagai interaksi. Baik interaksi dengan sesama peserta didik, bapak atau ibu guru, lingkungan bahkan sumber belajar yang lainnya (Kemendikbud, 2013). Dengan begitu peserta didik akan lebih peka terhadap ilmu yang diperolehnya selama belajar dengan kehidupan pada kesehariannya.

Proses pembelajaran seperti ini dapat diterapkan pada semua mata pelajaran, salah satunya adalah mata pelajaran fisika. Peserta didik diharapkan lebih peka terhadap apa yang mereka pelajari dengan apa yang mereka alami pada kehidupan. Seperti pada Kompetensi Dasar (KD) 3.2 fisika SMA kelas XI kurikulum 2013 yaitu "Menganalisis sifat elastisitas bahan dalam kehidupan sehari-hari" dan 4.2 "Melakukan percobaan tentang sifat elastisitas bahan berikut hasil percobaan dan pemanfaatannya". Dua KD ini membahas mengenai elastisitas bahan dan terdapat dua penilaian yaitu penilaian kognitif dan keterampilan. Karena materi ini sering dijumpai dalam kehidupan sehari-hari maka salah satu pendekatan yang cocok digunakan pada materi ini adalah pendekatan berbasis kontekstual.

Pendekatan berbasis kontekstual merupakan proses pembelajaran yang dilakukan dengan menghubungkan materi pembelajaran dan berbagai fenomena yang ada pada kehidupan nyata (Sagala, 2011). Dengan pendekatan kontekstual ini diharapkan peserta didik lebih mudah dan menyenangkan dalam belajar mengenai materi elastisitas.

Untuk mendukung pembelajaran berbasis kontekstual ini diperlukan Lembar Kerja Peserta Didik (LKPD). LKPD merupakan salah satu media belajar yang berupa bentuk lembaran kertas yang berisi dengan ringkasan materi serta petunjuk kegiatan belajar yang mengacu pada $\mathrm{KD}$, indikator dan tujuan yang akan dicapai oleh peserta didik (Prastowo, 2015). Selain itu menurut Farda (2017) LKPD merupakan kumpulan pertanyaan yang telah disusun sehingga peserta didik yang mengerjakannya diharapkan dapat menemukan konsep secara mandiri dengan bantuan seorang guru. Sehingga dirasa pengembangan LKPD berbasis kontekstual cocok untuk dilakukan pada materi elastisitas bahan ini. Adanya LKPD akan membantu seorang guru maupun peserta didik untuk mendapatkan hasil yang lebih maksimal dalam proses pembelajaran. 
Selain itu penggunaan LKPD ini membantu seorang guru dalam melakukan penilaian kognitif dan keterampilan sesuai standar kurikulum 2013 yang dianut saat ini. Seperti yang sudah dijelaskan oleh Farda (2017) peserta didik akan mengasah keterampilannya untuk menemukan konsep dalam LKPD yang telah dikerjakan.

Namun, hingga saat ini belum ada penelitian pengembangan LKPD berbasis kontekstual untuk materi elastisitas bahan ini. Beberapa penelitian yang mengangkat topik elastisitas bahan yaitu Alfionita, dkk (2016) pengembangan LKS elastisitas bahan berbasis inkuiri terbimbing; Sari (2016) pengembangan modul pembelajaran menggunakan Learning Conten Development System (LCDS) materi elastisitas bahan; Nuraini, dkk (2018) pengembangan LKS Blended Learning berorientasi Higher Order Thinking Skilss; Yunita, dkk (2017) desain LKPD berorientasi kompleksitas konten; dan Shabila, dkk (2020) pengembangan LKPD berbasis STEM. Dari beberapa penelitian diatas membuktikan bahwa belum ada penelitian mengenai pengembangan LKPD berbasis kontekstual unutk materi elastisitas bahan.

Berdasarkan paparan latar belakang tersebut, penelitian kali ini bertujuan untuk menghasilkan LKPD berbasis kontekstual yang valid dan praktis pada mata pelajaran fisika SMA kelas XI materi elastisitas bahan.

\section{METODE PENELITIAN}

Metode penelitian yang digunakan kali ini adalah model 4-D (Define, Design, Development and Disseminate). Namun tanpatahap Desseminate (penyebaran). Tahap pengembangan LKPD dengan materi elastisitas bahan ini dilakukan di jurusan Fisika FMIPA Universitas Negeri Surabaya dan uji coba terbatas yang dilakukan secara daring dengan 20 peserta didik SMA kelas XI yang ada di kabupaten Gresik pada bulan februari 2021.

Untuk tahap pertama yang dilakukan adalah tahap define yaitu dengan melakukan beberapa analisis, seperti analisis kurikulum, peserta didik, tugas serta konsep LKPD yang ingin dikembangkan. Setelah melakukan tahap pertama dan dirasa informasi yang didapat cukup kemudian dilakukan tahap kedua yaitu Design. Pada tahap ini merupakan tahapan memulai rancangan LKPD yang berbasis kontekstual.
Dengan memberikan fenomena serta benda apa saja yang relevan dengan materi elastisitas bahan ini dan bagaimana cara penyampaian agar tujuan LKPD ini sendiri tersampaikan kepada peserta didik. Setelah itu dilanjutkan dengan tahapan Development. Pada tahapan ini dilakukan pengembangan untuk LKPD berbasis kontekstual serta pengembangan terhadap perangkat pembelajaran pendukungnya, seperti silabus, RPP, Handout, buku panduan hingga latihan soal yang mendukung. Pada tahapan ini juga dilakukan proses validasi dengan dua validator ahli media dan dilanjut tahapan uji kepraktisan dari LKPD ini dengan membagikan kuisoner respons yang diberikan kepada 20 peserta didik SMA kelas XI di kabupaten Gresik.

Instrumen validasi pada penelitian ini diadaptasi dari Ridwan (2013) yaitu menggunakan skala Likert. Dengan setiap perangkat berbeda, meliputi: (1) LKPD aspek yang dinilai adalah kelayakan komponen isi, kelayakan penyajian dan kebahasaan, (2) Buku Panduan aspek yang dinilai adalah mengenai isi dari buku, (3) Handout aspek yang dinilai adalah kelayakan komponen isi, kelayakan penyajian dan kebahasaan, (4) Latihan soal aspek yang dinilai adalah kesesuaian soal dengan indikator dan materi, (5) Silabus aspek yang dinilai komponen pada silabus dan kesesuaian dengan materi, dan (6) RPP aspek yang dinilai adalah format RPP, isi RPP, kebahasaan, serta manfaat RPP. Skala Likert yang digunakan terlihat pada Tabel 1.

\begin{tabular}{|c|c|}
\hline Skala & Kategori \\
\hline 4 & Sangat Baik \\
\hline 3 & Baik \\
\hline 2 & Cukup Baik \\
\hline 1 & Kurang Baik \\
\hline
\end{tabular}

Validator akan memberikan nilai dengan skala diatas yang kemudian akan diolah presentase keberhasilan dari LKPD beserta perangkat pembelajaran menggunakan perhitungan :

$$
\text { Skor validitas }=\frac{\Sigma \text { skor yang diperoleh }}{\Sigma \text { skor maksimal }} \times 100 \%
$$

Sesuai dengan Riduwan dan Akdon (2013), hasil intepretasi dapat dinyatakan valid jika memenuhi ketentuan berikut sesuai dengan Table 2. 
Tabel 2. Presentase validitas dan kriteria interpretasinya

\begin{tabular}{cc}
\hline Presentase (\%) & Kriteria Interpretasi \\
\hline $0-20$ & Sangat tidak valid \\
$21-40$ & Kurang valid \\
$41-60$ & Cukup valid \\
$61-80$ & Valid \\
$81-100$ & Sangat valid \\
\hline
\end{tabular}

Setelah melakukan proses validasi, maka akan dilakukan proses uji kelayakan dengan membagikan angket respons kepada 20 peserta didik SMA kelas XI di kabupaten Gresik. Teknis pengambilan data yang digunakan menggunakan skala Guttaman yang diadaptasi dari Ridwan (2013), seperti yang tertera pada Tabel 3.

Tabel 3. Skala Guttaman untuk respon uji

\begin{tabular}{cc}
\multicolumn{2}{c}{ kelayakan } \\
\hline Jawaban & Nilai/Skor \\
\hline Ya & 1 \\
Tidak & 0 \\
\hline
\end{tabular}

Respons yang diberikan oleh peserta didik tersebut, akan diolah dengan menggunakan perhitungan :

Skor validitas $=\frac{\Sigma \text { peserta yang menjawab ya }}{\Sigma \text { seluruh oeserrta yang merespons }} \times 100 \%$

Berdasarkan hasil interpretasi respons 20 peserta didik SMA kelas XI di kabupaten Gresik yang telah diolah, maka LKPD berbasis kontekstual dapat dikatakan layak dengan kategori sangat baik jika skor rata-rata $\geq 81 \%$.

\section{HASIL DAN PEMBAHASAN}

Penelitian ini menghasilkan produk berupa LKPD berbasis kontekstual dengan materi elastisitas bahan pada kelas XI SMA yang layak berdasarkan validitas dan praktis. Hasil dari pengembangan LKPD berbasis kontekstual ini berisi materi elastisitas bahan yang dikombinasi dengan kegiatan praktikum dengan menghubungkan manfaat dari kegiatan tersebut dengan fenomena atau benda yang sering dijumpai dalam kegiatan sehari-hari. Gambar 1 menunjukkan tampilan LKPD berbasis kontekstual yang telah dibuat. Pada Gambar 1 bagian (b), LKPD berbasis kontektual ini terdiri dari beberapa tahapan untuk memberikan dan menggali informasi peserta didik untuk lebih peka terhadap lingkungan sekitar. Tahapantahapan yang terdapat dalam LKPD ini yaitu dasar teori, ayo berfikir, ayo mencoba, dan ayo berfikir lebih dalam. Manfaat dari tahapan tersebut dapat dilihat pada Tabel 4.

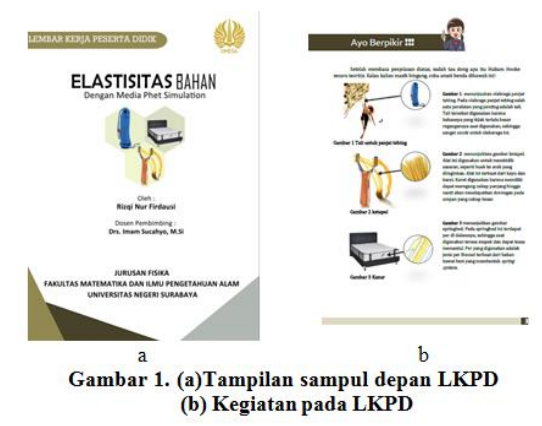

Tabel 4. Fitur pada LKPD

\begin{tabular}{|c|c|c|}
\hline No & Fitur & Deskripsi \\
\hline 1 & Dasar Teori & $\begin{array}{l}\text { Pada tahapan ini peserta } \\
\text { didik diberi informasi } \\
\text { sekilas } \\
\text { elastisitas bahan }\end{array}$ \\
\hline 2 & Ayo Berpikir "?! & $\begin{array}{lr}\text { Pada tahapan ini peserta } \\
\text { didik diminta untuk opini } \\
\text { awal mengenai fenomena } \\
\text { dan benda yang } & \text { sering } \\
\text { dijumpai } & \text { dalam } \\
\text { kehidupan } & \end{array}$ \\
\hline 3 & Ayo Mencoba :!? & $\begin{array}{l}\text { Pada tahapan ini peserta } \\
\text { didik diminta untuk } \\
\text { melakukan percobaan } \\
\text { menggunakan PhET }\end{array}$ \\
\hline & & $\begin{array}{l}\text { Pada tahapan ini peserta } \\
\text { didik diminta untuk } \\
\text { menganalisis opini awal } \\
\text { dengan hasil percobaan } \\
\text { yang telah ia lakukan lalu } \\
\text { menarik kesimpulan }\end{array}$ \\
\hline
\end{tabular}

Berdasarkan hasil pengembangan LKPD yang telah dibuat, selanjutnya dilakukan proses validasi oleh 2 orang validator ahli media dengan hasil bahwa LKPD berbasis kontekstual tersebut sangat valid dengan presentase 94\%. Hasil rincian validitas oleh para ahli dapat dilihat pada Tabel 5.

Tabel 5. Hasil validitas LKPD

\begin{tabular}{|c|c|c|c|c|c|}
\hline \multirow{2}{*}{ No } & \multirow{2}{*}{ Aspek yang dinilai } & \multicolumn{2}{|c|}{ Skor } & \multirow{2}{*}{$\begin{array}{l}\text { Skor } \\
(\%)\end{array}$} & \multirow{2}{*}{ Kategori } \\
\hline & & $\mathbf{V}_{1}$ & $\mathbf{V}_{2}$ & & \\
\hline \multicolumn{6}{|c|}{ Kelayakan Komponen Isi } \\
\hline 1 & $\begin{array}{l}\text { Sesuai dengan materi } \\
\text { Kompetensi Dasar }\end{array}$ & 4 & 4 & 100 & SV \\
\hline 2 & Sesuai dengan materi & 4 & 4 & 100 & SV \\
\hline
\end{tabular}




\begin{tabular}{|c|c|c|c|c|c|}
\hline 4 & $\begin{array}{l}\text { pembelajaran } \\
\text { Mencakup tujuan } \\
\text { pembelajaran } \\
\text { Berkaitan dengan } \\
\text { kehidupan sehari-hari }\end{array}$ & 4 & 3 & 88 & SV \\
\hline & Rata-rata & & & 94 & SV \\
\hline \multicolumn{6}{|c|}{ Kelayakan Penyajian } \\
\hline 1 & $\begin{array}{l}\text { Memberikan ilustrasi } \\
\text { yang sesuai }\end{array}$ & 4 & 3 & 88 & SV \\
\hline 2 & $\begin{array}{l}\text { Memberikan } \\
\text { sistematika yang sesuai }\end{array}$ & 4 & 4 & 100 & SV \\
\hline 3 & $\begin{array}{l}\text { Mempermudah peserta } \\
\text { didik dalam } \\
\text { membayangkan }\end{array}$ & 4 & 4 & 100 & SV \\
\hline 4 & $\begin{array}{l}\text { Menarik perhatian } \\
\text { peserta didik }\end{array}$ & 4 & 4 & 100 & SV \\
\hline
\end{tabular}

\section{Kebahasaan}

1 Gaya bahasa yang

digunakan jelas

$\begin{array}{llllll}2 & \text { Konsistensi penggunaan } & 4 & 3 & 88 & \text { SV }\end{array}$

2 bahasa tepat

3 Konsistensi penggunaan

\begin{tabular}{ccccc}
$3 \begin{array}{l}\text { Konsistensi penggunaan } \\
\text { istilah tepat }\end{array}$ & 4 & 4 & 100 & SV \\
\hline Rata-rata & & & $\mathbf{9 2}$ & SV \\
\hline $\begin{array}{c}\text { Rata-rata seluruh aspek } \\
\text { penilaian }\end{array}$ & $\mathbf{4}$ & $\mathbf{4 , 2}$ & $\mathbf{9 4}$ & $\mathbf{S V}$ \\
\hline
\end{tabular}

Selain melakukan validasi pada LKPD, tim ahli media juga memvalidasi perangkatperangkat pendukung yang telah dibuat. Hasil yang didapatkan, setiap perangkat yang dibuat sangat valid. Tabel 6 berikut akan menunjukkan rincian hasil validitas perangkat pembelajaran pendukung:

Tabel 6. Hasil validitas perangkat pendukung

\begin{tabular}{clcc}
\hline No & \multicolumn{1}{c}{ Perangkat } & Skor $(\%)$ & Kategori \\
\hline 1 & Buku Panduan & 98 & SV \\
2 & Handout & 95 & SV \\
3 & Latihan soal & 96 & SV \\
4 & RPP & 96 & SV \\
5 & Silabus & 94 & SV \\
& Karena hasil & Validitas & LKPD
\end{tabular}

kontekstual serta perangkat pembelajaran pendukungnya sangat valid, maka dilanjutkan pada tahap uji coba terbatas yang diujikan pada 20 siswa SMA kelas XI secara acak dari berbagai sekolah SMA yang ada di kabupaten Gresik. Gambar 2 merupakan pengarahan dalam pengisian respons.

Hasil dari uji coba yang dilakukan juga menunjukkan bahwa LKPD berbasis kontekstual pada materi elastisitas bahan ini sangat praktis, dengan rincian yang dijelaskan pada Tabel 7 .

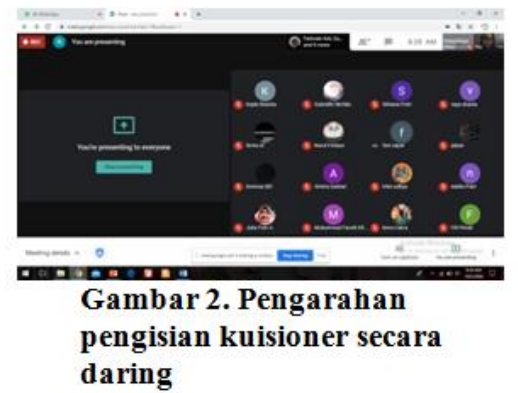

Tabel 7. Hasil uji coba terbatas pada siswa SMA kelas XI di kabupaten Gresik

\begin{tabular}{|c|c|c|c|c|}
\hline \multirow[t]{2}{*}{ No } & \multirow[t]{2}{*}{ Uraian } & \multicolumn{2}{|c|}{$\begin{array}{l}\text { Jumlah } \\
\text { Jawaban }\end{array}$} & \multirow{2}{*}{$\begin{array}{l}\text { Skor } \\
(\%)\end{array}$} \\
\hline & & Ya & Tidak & \\
\hline 1 & $\begin{array}{l}\text { Apakah petunjuk LKPD } \\
\text { mudah dipelajari? }\end{array}$ & 20 & - & 100 \\
\hline 2 & $\begin{array}{l}\text { Apakah prosedur dalam } \\
\text { LKPD mudah dipahami? }\end{array}$ & 20 & - & 100 \\
\hline 3 & $\begin{array}{l}\text { Apakah dengan LKPD ini } \\
\text { lebih mudah menguasai } \\
\text { konsep? }\end{array}$ & 20 & - & 100 \\
\hline 4 & $\begin{array}{l}\text { Apakah LKPD membantu } \\
\text { bahwa fisika erat kaitannya } \\
\text { dengan kehidupan? }\end{array}$ & 18 & 2 & 90 \\
\hline 5 & $\begin{array}{l}\text { Apakah LKPD ini } \\
\text { membantu dalam materi } \\
\text { "Elastisitas Bahan" }\end{array}$ & 19 & 1 & 95 \\
\hline 6 & $\begin{array}{l}\text { Apakah bahasa yang } \\
\text { digunakan mudah dipahami? }\end{array}$ & 20 & - & 100 \\
\hline 7 & $\begin{array}{l}\text { Apakah tulisan dalam LKPD } \\
\text { mudah dibaca? }\end{array}$ & 20 & - & 100 \\
\hline 8 & $\begin{array}{l}\text { Apakah secara keseluruhan } \\
\text { LKPD ini sudah baik? }\end{array}$ & 20 & - & 100 \\
\hline 9 & $\begin{array}{l}\text { Apakah anda suka dengan } \\
\text { LKPD ini? }\end{array}$ & 19 & 1 & 95 \\
\hline 10 & $\begin{array}{l}\text { Apakah anda merasa senang } \\
\text { dapat menyelesaikan LKPD } \\
\text { ini? }\end{array}$ & 19 & 1 & 95 \\
\hline \multicolumn{2}{|c|}{ Rata-rata } & & & 98 \\
\hline \multicolumn{2}{|c|}{ Kategori } & & \multicolumn{2}{|c|}{ Sangat Baik } \\
\hline
\end{tabular}

Berdasarkan hasil validitas LKPD berbasis kontekstual pada materi elastisitas bahan yang ditunjukkan oleh Tabel 5, dihasilkan rata-rata validitasnya sebesar $94 \%$ yang dimana menurut Riduwan dan Akdon(2013) menandakan sangat valid. Dan berdasarkan aspek-aspek yang tertera, LKPD berbasis kontekstual ini sesuai dengan kriteria penyusunan LKPD. Hal tersebut menandakan bahwa LKPD berbasis kontekstual ini baik dan layak untuk digunakan pada pembelajaran fisika SMA kelas XI.

Pada rubrik validasi terdapat tahapan yang pertama yaitu aspek kelayakan komponen isi dengan poin (1) materi pada kompetensi dasar 
(2) materi pembelajaran (3)tujuan pembelajaran dan (4) selaras dengan fenomena dalam kehidupan. Untuk 2 poin pertama didapatkan hasil yang maksimal, namun pada poin 3 dan 4 belum maksimal meskipun hasilnya sangat valid. Hal ini dikarenakan pada LKPD belum mencakup tujuan pembelajaran secara keseluruham, hanya terfokus pada menganalisis materi dengan fenomena disekitar. Selain itu fenomena yang diberikan hanya ada tiga sehingga peserta didik masih dirasa masih kurang maksimal. Namun secara keseluruhan komponen ini sudah baik dengan hasil validitas yang didapat sebesar 94\%. Dimana menandakan bahwasannya LKPD ini sesuai dengan kurikulum yang berlaku pada saat ini, diperkuat dengan adanya indikator pembelajaran dan tujuan pembelajaran yang dijelaskan pada perangkat pembelajaran berupa silabus dan RPP. Hal ini sesuai dengan depdiknas (2008) yang menyatakan bahwa bahan ajar yang digunakan pada saat kegiatan belajar mengajar harus sesuai dengan tuntutan kurikulum yang ada.

Komponen yang kedua adalah kelayakan komponen penyajian. Poin penilaian pada komponen ini meliputi : (1) kesesuaian ilustrasi, (2) sistematika, (3) penyampaian kepada peserta didik, dan (4) dapat menarik peserta didik. Pada poin (2), (3), dan (4) didapatkan hasil yang maksimal. Namun, pad poin (1) hasil yang didapatkan kurang maksimal sebab ilustrasi yang diberikan kuramg mengarahkan peserta didik pada rumusan masalah (Atmaja, 2018). Dengan presentase validitas sebesar 96\%. Menandakan bahwasannya secara keseluruhan LKPD berbasis kontekstual ini telah disajikan secara runtut, jelas, materi yang diberikan cukup serta mampu menunjang proses pembelajaran. Selain itu menurut Depdiknas (2008) komponen penyajian harus jelas mulai dari tujuan yang ingin dicapai, tampilan yang disajikan, memiliki saya tarik serta informasi yang diberikan harus lengkap.

Komponen yang terakhir adalah kebahasaan, dengan poin: (1) gaya bahasa jelas; (2) konsistensi penggunaan bahasa; (3) konsistensi penggunaan istilah. Pada poin k3 (3) mendapatkan validitas yang sempurna sedangkan pada poin (1) dan (2) kurang maksimal karena penggunaan bahasa yang kurang ringkas dan terdapat pengulangan kalimat yang kurang tepat. Namun, secara keseluruhan kebahasaan yang digunakan sangat valid. Hasil yang didapat sebesar 92\%, artinya, secara jesekuruhan bahasa yang disajikan oleh LKPD ini dapat tersampaikan kepada peserta didik dengan jelas. Sehingga dapat membantu seorang guru untuk menyempaikan materi kepada peserta didik.

Secara keseluruhan LKPD berbasis kontekstual untuk materi elastisitas bahan ini layak untuk digunakan dalam kegiatan belajar mengajar. Sesuai dengan Prastowo (2015) terdapat empat poin tujuan dari pembuatan LKS, yaitu (1) menyajikan bahan ajar yang memudahkan peserta didik, sehingga peserta didik dapat berinteraksi atau menangkap materi yang diberikan dengan mudah, (2) menyajikan tugas yang dapat meningkatkan penguasaan pemahaman dari peserta didik terhadap materi yang diberikan, (3) melatih kemandirian belajar peserta didik dalam belajar, dan (4) memudahkan pendidik dalam memberikan tugas kepada peserta didik. Dan diperkuat Widodo (2017) terdapat empat poin tujuan dari pembuatan LKS, yaitu (1) menyajikan materi dan tugas sebagai penyelesaian permasalahan; (2) melatih kepekaan peserta didik dengan permasalah sekitar; (3) memudahkan peserta didik dalam menyelesaikan masalah dilingkungan sekitar. Karena pada LKPD berbasis kontekstual ini telah dirancang menarik, sesuai dengan kurikulum yang berlangsung, konten yang disajikan relevan dengan fenomena dan benda yang mudah dijumpai sehari-hari sehingga peserta didik lebih mudah memahami, serta bahasa yang disampaikan juga mudah dipahami.

Pada Tabel 6 berisi tentang hasil validitas perangkat pembelajaran pendukung. Secara keseluruhan, hasil dari perangkat tersebut sangat valid yang menandakan telah relevan dengan LKPD yang dibuat. Sehingga dapat digunakan dalam praktik kegiatan belajar mengajar.

Pada Tabel 7 berisi tentang hasil uji coba terbuka yang dilakukan uji coba tersebut terhadap peserta didik SMA kelas XI secara acak di kabupaten Gresik. Dari 10 poin yang diberikan dalam lembar respon terdapat 3 poin yang mendapatkan hasil kurang maksimal. 2 dari 20 peserta didik mengatakan bahwasannya LKPD ini kurang membantu makna fisika dekat dengan kehidupan, 1 dari 20 peserta didik kurang suka dengan LKPD dan kurang senang dapat menyelesaikan LKPD ini. Hal tersebut sesuai 
dengan hasil validitas pada bagian ilustrasi dan penggunaan bahasa yang kurang. Namun, secara keseluruhan hasil uji coba tersebut dinyatakan bahwa LKPD berbasis kontekstual ini sangat baik untuk digunakan dengan presentase $98 \%$. Sesuai dengan Pramaditya (2021) hasil respon LKPD siswa masuk kategori sangat baik menandakan siswa merespons dengan positif LKPD tersebut dan praktis untuk digunakan. Dengan respon positif yang diberikan peserta didik maka LKPD berbasis kontekstual pada materi elastisitas bahan ini praktis untuk digunakan pada kegiatan belajar mengajar dan menjadikan salah satu inovasi yang bisa dikembangkan pada materi lain.

\section{KESIMPULAN}

Berdasarkan hasil penelitian dan pembahasan dapat disimpulkan bahwa LKPD berbasis kontekstual yang dikembangkan untuk materi elastisitas bahan ternyata sangat valid dan sangat praktis. Sehingga LKPD berbasis kontekstual ini dapat digunakan dalam kegiatan belajar mengajar pada mata pelajaran fisika SMA kelas XI dengan materi elastisitas bahan.

\section{DAFTAR PUSTAKA}

Alfionita, Sinta., Chandara Ertikanto., I Dewa Putu Nyeneng. (2016). Pengembangan LKS Berbasis Inkuiri Terbimbing Pada Materi Elastitas Dan Hukum Hooke. Jurnal Pembelajaran Fisika Universitas Lampung:127-138.

Atmaja, Putri Bunga Sari Surya. (2018). Kevalidan Lembar Kerja Peserta Didik (LKPD) Berorientasi Problem Based Learning unutk Melatih Keterampilan Pemecahan Masalah.Pensa E-Jurnal. 6(02): 399-403.

Depdiknas. (2008). Panduan Pengembangan Bahan Ajar. Jakarta: Departemen Pendidikan Nasional Jendral Manajemen Pendidikan Dasar dan Menengah

Farda, H. (2017). Keefektifan Model Pembelajaran POGIL Bernuansa Etnomatematika Berbantuan LKPD terhadap Kemampuan Komunikasi Matematis Siswa. Unnes Journal of Mathematics Education. 6(2). hal 223- 230.

Kemendikbud. 2013. Salinan Peraturan Menteri Pendidikan dan Kebudayaan Republik
Indonesia Nomor 71 tahun 2013 tentang Buku Teks Pelajaran dan Buku Panduan Guru untuk Pendidikan Dasar dan Menengah.

Nuraini, Syifa., I Wayan Distrik, Wayan Suana. (2018). Pengembangan Lembar Kerja Siswa Blended Learning Berorientasi Higher Order Thinking Skilss. Journal of Physics and Science Learning, 2(1): 69-77.

Pramaditya, Novangga Dwiky. 2021. Validitas dan Kepraktisan LKPD Berbasis Keterampilan Proses Sains Materi Keanekaragaman Hayati Kelas X SMA. BioEdu. 10(1): 158-164.

Prastowo, A. (2015). Panduan Kreatif Membuat Bahan Ajar Inovatif: Menciptakan Metode Pembelajaran yang Menarik dan Menyenangkan. Yogyakarta: Diva Press.

Riduwan \& Akdon. (2013). Rumus dan Data Dalam Analisis Statistika. Bandung:Alfabeta

Ridwan. (2013). Skala-Skala Pengukuran Variabel-Variabel Penelitian. Bandung: Alfabeta

Sagala, S. (2011). Konsep dan Makna Pembelajaran. Bandung: Alfabeta.

Sari, Nurmala. (2016). Pengembangan Modul Pembelajaran Menggunakan Learning Content Development System (LCDS) untuk materi elastisitas Bahan dan Hukum Hooke. Digital [Skripsi]. Lampung (ID): Universitas Lampung.

Shabila, Reihan Laila., Yoga Budi Bhakti., Fatahillah. (2020). Pengembangan LKPD berbasis STEM (Science, Technology, Engineering, Mathematic) pada Materi Elastisitas dan Hukum Hooke. Schrodinger. 1(2): 95-100.

Widodo, Slamet. (2017). Pengembangan LKPD Berbasis Pendekata Saintifik untuk Meningkatkan Keterampilan Penyelesaian Masalah Lingkungan Sekitar Peserta Didik di Sekolah Dasar. Jurnal Pendidikan Ilmu Sosial. 26(2): 189-204.

Yunita, Vera., Amali Putra., Harman Amir. (2017). Desain LKPD Berorientasi Konten dan Proses Kognitif pada Materi Elastis untuk Pembelajaran Fisika SMA/MA. Pillar of Physichs Education. 9(2017): 177-184.

Yusmanila., Amran Hasra., Pakhrul Razi. (2017). Pengembangan Bahan Ajar dalam Bentuk 
Modul Fisika Kontekstuual pada Materi Fluida dalam Pembelajaran Fisika di SMA/MA. Jurnal Gravity. 3(2): hal 134-147.

Zulhaini, A. Halim, Mursal. (2016). Pengembangan Modul Fisika Kontekstual Hukum Newton Untuk Meningkatkan Pemahaman Konsep Fisika Siswa di MAN Model Banda Aceh. JPSI. 04(01): hal 196207. 